\title{
Konsep Persamaan Diferensial Model Eksponensial dalam Menjelaskan Kasus Positif COVID-19 di Jakarta dan Solusi Menurunkannya
}

\author{
Johan Gopas Pasaribu ${ }^{1, a)}$, Lusi Afriana Malau, b), Suci Hartati, ${ }^{1, c)}$ \\ Fakultas MIPA, Universitas Negeri Medan \\ a) johanpasa900@gmail.com \\ b) lusiafrianamalau@gmail.com \\ c) Sucihartati325@gmail.com
}

\begin{abstract}
This study focuses on the reason why the COVID-19 outbreak is a serious problem by linking it to the ordinary linear equation and proving a good contribution if we adhere to health protocols to the decline in COVID-19 cases. The purpose of this research is for the public to be more concerned about health protocols and vaccinations. Recognize that COVID-19 is a serious problem, because we will explain it in data and mathematics. This research method we do by taking COVID-19 case data in DKI Jakarta, and analyzing the data using literature review methods sourced from several mathematics books.
\end{abstract}

Keywords Research Results: COVID-19;Ordinary Differential Equations; Health Protocols; Vaccinations.

\section{Pendahuluan}

Kasus COVID-19 adalah kasus yang pada awal kemunculannya sangatlah mengemparkan dunia, menurut sumber yang kami dapat banyak negara di dunia ini yang melaporkan kasus pertama COVID-19 pada januari 2020. Sedangkan Indonesia pertama kali mengkonfimasikan kasus COVID-19 pada Senin, 2 Maret 2020 . Kasus pertama COVID-19 di Indonesia dimulai dengan dua orang WNI yang tinggal di Depok diketahui terkonfirmasi positif COVID-19, keduanya diketahui pernah berkontak langsung dengan WNA asal Jepang yang diketahui telah terkonfirmasi positif terlebih dahulu. Seperti yang kita tahu Sebelumya, COVID - 19 ini adalah penyakit yang disebabkan oleh Virus, dan Virus ini dapat menyebar melalui kontak langsung seperti berjabat tangan, bersin, dan bisa melewati peralatan makan dan minum yang kita gunakan , dan menurut sumber yang kami dapat Virus ini berkerja dengan cara menginfeksi metabolisme yang ada pada sel tubuh kita , sehingga sel tersebut tidak bisa menjalankan fungsinya dengan baik dan membuat virus tersebut berkembang sangat banyak, dan menyebar pada sel tubuh yang lain. Setelah mengetahui bahwa COVID-19 ini adalah penyakit yang cukup serius.oleh karena itu, kami ingin melakukan penulisan karya ilmiah ini sebagai pengingat bagi para pembaca bahwa COVID-19 ini adalah masalah serius dan harus tetap protokol kesehatan , di sini kami juga melibatkan Persamaan Diferensial Biasa untuk membuktikan bahwa kasus ini adalah kasus serius, dan bagaimana upaya yang harus kita lakukan untuk menurunkan kasus ini.Persamaan Diferensial menarik bagi non-matematika karena biasanya digunakan untuk menyelidiki berbagai macam masalah fisika,biologi,dan ilmu sosial.Salah satu alasannya model matematika dan solusinya mengarah pada persamaan yang menghubungkan variabel parameter dalam masalah.Persamaan ini sering memungkinkan anda untuk membuat prediksi tentang bagaimana alam akan berprilaku. (Boyce William, 2008). Persamaan Diferensial biasa orde pertama merupakan persamaan diferensial biasa yang paling sederhana bentuknya karena hanya mengandung turunan pertama dari suatu fungsi. Suatu persamaan linear orde satu adalah persamaan linear yang berbentuk

$$
a_{1}(x) y^{\prime}+a_{0}(x) y=f(x)
$$


kita akan memisahkan koefisien-koefiien $\mathrm{a}_{1(\mathrm{x})}, \mathrm{a}_{0}(\mathrm{x})$, dan fungsi $\mathrm{f}(\mathrm{x})$

$$
\mathrm{a}(\mathrm{x})=\frac{\mathrm{a} 0(\mathrm{x}}{a 1(x)} \quad \operatorname{dan} \mathrm{b}(\mathrm{x})=\frac{\mathrm{f}(\mathrm{x})}{a 1(x)}, \mathrm{a}_{1(\mathrm{x})} \neq 0
$$

kita akan memperoleh persamaan yang sepadan yaitu

$$
y^{\prime}+a(x) y=b(x)
$$

dengan $\mathrm{a}(\mathrm{x})$ dan $\mathrm{b}(\mathrm{x})$ adalah fungsi - funsi kontinu . Penyelesaian umum persamaan dapat dicari secara eksplisit dengan memperhatikan perubahan peubah

$$
\mathrm{w}=\mathrm{y} e^{\int a(x) d x}
$$

kita akan memisahkan persamaan diferensial terseut menjadi :

$$
\frac{d}{d x}\left[\int a(x) d x\right]=a(x)
$$

akan diperoleh,

$$
\begin{gathered}
\mathrm{w}^{\prime}=\mathrm{y}^{\prime} e^{\int a(x) d x}+y a(x) e^{\int a(x) d x} \\
=\left[y^{\prime}+a(x) y\right] e^{\int a(x) d x} \\
=\mathrm{b}(\mathrm{x}) e^{\int a(x) d x} \cdot(\text { Nuraeni, 2017) }
\end{gathered}
$$

Hasil

Data last update 29 Oktober 2021

Data Monitoring on COVID-19 Cases

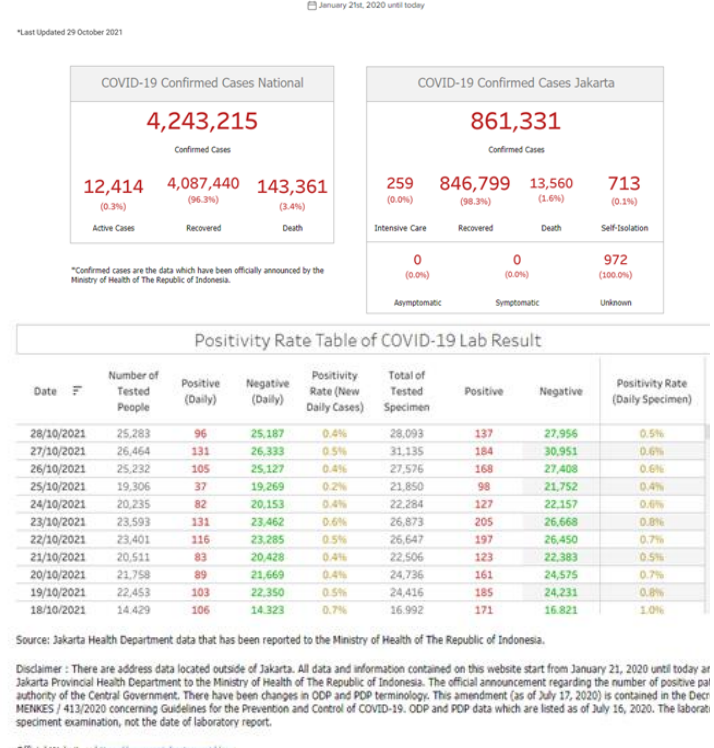

Data Covid-19 Dki Jakarta

\section{METODE PENELITIAN}

Penelitian ini dilakukan dengan metode literature review yang diambil dari beberapa sumber buku, dan dalam penyajian data, kami mengambil data kasus COVID-19 di jakarta melalui web https://corona.jakarta.go.id/id/data . Melalui web diatas kami dapatkan data yang akurat mengenai banyaknya kasus COVID-19 di jakarta. Setelah mengambil data kasus yang ada pada web tersebut kami mencoba menghubungkan kasus ini dengan bidang keilmuan matematika, yaitu Persamaan Diferensial Biasa, disini kami mengambil beberapa rumus yang relevan, dimana rumus - rumus itu kami dapatkan dari beberapa sumber buku dan jurnaljurnal.

Data diatas adalah data yang kami dapatkan dari web https://corona.jakarta.go.id/id/data. Data ini terakhir di update pada tanggal 29 Oktober 2021 . Dari data tersebut terlihat bahwa ada 4.243.215 kasus nasional yang terkonfirmasi,kasus aktif di Indonesia sebanyak 12.414 kasus , penyembuhan sebesar 4.087.440 , dan kasus kematian nasional sebesar 143.361. Di Jakarta kasus terkonfirmasi sebesar 861.331 kasus , perawatan intensive sebesar 259 , penyembuhan sebesar 846.799, kasus kematian sebesar 13.560 kasus, isolasi mandiri sebesar 713, tidak ada kasus tanpa gejala, tidak ada kasus dengan gejala, dan 972 yang tidak diketahui. 


\section{PEMBAHASAN}

Persamaan Diferensial Biasa memiliki hubungan yang erat dengan kalkulus karena pada dasar nya konsep dari persamaan diferensial biasa ini mengandung turunan pada berbagai orde, sedangkan turunan adalah sub bab yang kita telah pelajari di dalam kalkulus . Oleh karena itu untuk membahas kasus ini kami akan menerapkan konsep PDB dan kalkulus. Persamaan Diferensial Biasa ini banyak sekali manfaat nya, terutama dibidang pemodelan matematika, dan terutama pada kasus COVID - 19 ini , karena pada kasus COVID-19 ini perkembangan kasus nya dapat berubah- ubah dipengaruhi oleh laju pertumbuhan kasusnya dari hari ke hari.

kami akan membahas kasus ini pada persamaan diferensial biasa orde satu. Kami misalkan $s(t)$ adalah banyaknya pertambahan virus COVID-19, s(t) adalah fungsi yang kontinu karena $\mathrm{s}(\mathrm{t})$ ini fungsi yang diturunkan terhadap waktu. Maka kami akan menganggap $\frac{\mathrm{ds}}{d t}$, laju pertambahan kasus covid-19 terhadap jumlah yang ada, maka $\frac{\mathrm{ds}}{d t}=r S$, atau $\frac{\mathrm{ds}}{d t}-r S=$ 0 , t adalah konstanta . Pada model ini kami menganggap bahwa pertambahan kasus COVID-19 bertambah dengan laju pertambahan orang yang terkonfirmasi COVID-19 dengan besarnya populasi. Misalnya S(t) menyatakan banyaknya kasus pada saat $\mathrm{t}$ (waktu), dan $\mathrm{r}$ menyatakan laju pertumbuhan kasus, maka akan kami nyatakan dalam bentuk PDB model eksponensial menjadi

$$
\frac{\mathrm{d} s}{d t}=r S(t)
$$

Kami akan membentuknya menjadi persamaan diferensial terpisah, sehingga solusi umumnya akan didapatkan sebagai berikut :

$$
\begin{gathered}
\frac{\mathrm{ds}}{s}=r \mathrm{dt} \\
\int \frac{\mathrm{ds}}{s}=\int r d t \\
\ln \mathrm{S}(\mathrm{t})=\mathrm{rt}+\mathrm{c}
\end{gathered}
$$

$$
\begin{aligned}
& e^{\ln s(t)}=e^{r t+c} \\
& \mathrm{~S}(\mathrm{t})=e^{r t+c}
\end{aligned}
$$

Jika diberikan kondisi awal $\mathrm{t}=0$ dan $\mathrm{S}(0)=\mathrm{S}_{0}$, maka jika kita substitusi akan didapatkan $\mathrm{c}=\ln \mathrm{S}_{0}$, apabila nilai $\mathrm{c}$ disubtitusikan ke persamaan akan diperoleh :

$$
\begin{aligned}
& \mathrm{S}(\mathrm{t})=e^{r t+\ln \mathrm{S} 0} \\
& \mathrm{~S}(\mathrm{t})=e^{r t} e^{\ln \mathrm{S} 0} \\
& \mathrm{~S}(\mathrm{t}) \quad=\mathrm{S}_{0} e^{r t}
\end{aligned}
$$

Persamaan diatas merupakan bentuk solusi khusus dari persamaan diferensial biasa model eksponensial. Dari persamaan tersebut jika $\mathrm{r}$ positif maka kasus akan meningkat secara eksponensial, jika r negtif maka kasus akan menurun. (Nuraeni, 2017) (Arif Kurniawan, 2017)

Sekarang kita akan kembali kepada data kasus COVID19

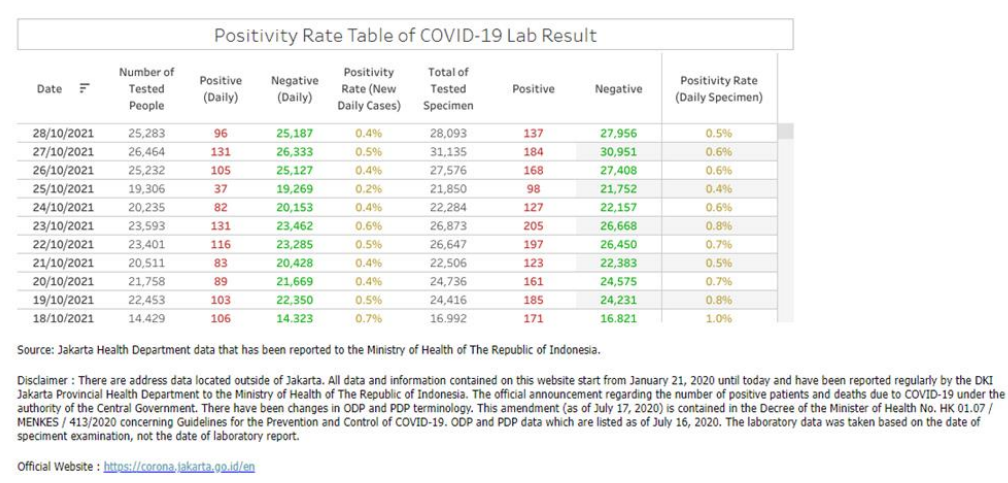

Dari data diatas kami akan mengambil 5 sampel untuk dibahas yaitu data dari tanggal 24-28 Oktober 2021, dengan $\mathrm{S}(\mathrm{t})$ adalah banyaknya kasus positif. Kalau kita lihat data diatas data kasus positif itu fluktuatif, terlihat dari adanya kenaikan dan penurunan kasus positif COVID-19 dari data tersebut. Disini kami akan memodelkan kasus ini dalam model eksponensial, dalam hal ini kami akan menggunakan konsep $\frac{\mathrm{ds}}{d t}-r S$ $=0$, pertama yang akan kita cari adalah koefisien $\mathrm{r}$ nya terlebih dahulu dan kami menganggap data tanggal 24 Oktober 2021 sebagai S(0) ( kasus awal) dan S(t) adalah 
jumlah kasus positif setelah t hari dari 24 Oktober 2021 .Dengan demikian, data diatas kami bentuk menjadi seperti berikut.

\begin{tabular}{|c|c|}
\hline Hari ke-t & $\mathrm{S}(\mathrm{t})$ \\
\hline $\mathrm{t}=0$ & 82 \\
\hline $\mathrm{t}=1$ & 37 \\
\hline $\mathrm{t}=2$ & 105 \\
\hline $\mathrm{t}=3$ & 131 \\
\hline $\mathrm{t}=4$ & 96 \\
\hline
\end{tabular}

Solusi masalah kasus positif ini jika kita modelkan kedalam PDB model eksponensial adalah dengan bentuk $\mathrm{S}(\mathrm{t})=\mathrm{S}_{0} e^{r t}$. Untuk mencari nilai $\mathrm{r}$, kami substitusikan nilai $\mathrm{t}=1$ dengan $\mathrm{S}(1)=37$ dan $\mathrm{t}=4$

dengan $\mathrm{s}(4)=96$.

$$
37=\mathrm{S}_{0} e^{r}
$$

Substitusi $\mathrm{t}=4, \mathrm{~S}(\mathrm{t})=96$

$$
96=\mathrm{S}_{0} e^{4 r}
$$

Dari kedua persamaan diatas , kami menemukan bahwa

$$
r=0,317810093
$$

Dengan demikian, kami dapat mengestimasi/memperkirakan jumlah kasus positif pada setiap hari dengan jumlah kasus positif pada 24 Oktober 2021 sebagai $\mathrm{S}_{0}$

$$
\mathrm{S}(\mathrm{t})=37 \times \mathrm{e}^{0,317810093 \mathrm{t}}
$$

sebagai contoh, estimasi jumlah kasus covid-19 pada tanggal 3 November 2021 S(10), yaitu :

$$
\mathrm{S}(10)=37 \times \mathrm{e}^{0,317810093(10)}=888 \text { kasus }
$$

Jadi, estimasi/ perkiraan yang kami dapatkan untuk kasus positif tanggal 3 November 2021 adalah 888 kasus positif di jakarta .

\section{KESIMPULAN}

Persamaan Diferensial dan Kalkulus adalah dua bidang ilmu yang banyak sekali pemanfaatannya di bidang kehidupan . Persamaan Diferensial ini sangat berhubungan dengan kalkulus karena konsep yang disajikan dalam persamaan diferensial adalah konsepkonsep yang diambil dari kalkulus, pada persamaan diferensial kita juga harus mampu mengintegralkan persamaan tersebut untuk mendapatkan solusi umumnya. Dari pembahasan yang sudah kami paparkan diatas, hasil yang kami dapatkan adalah sebuah estimasi/ perkiraan kami mengenai jumlah kasus positif COVID-19 di jakarta menggunakan kosep persamaan diferensial model eksponensial, untuk data sebenarnya bisa di lihat pada website yang sudah kami sajiakan diawal. melihat hasil estimasi/perkiraan yang telah kami bahas sebelumnya, kami berkesimpulan bahwa kasus positif COVID-19 terutama di jakarta bisa saja menurun kalau konstanta (r) nya itu diperkecil, karena menurut analisa kami, yang kami dapatkan dari konsep persamaan diferensial model eksponensial, kasus ini sangat dipengaruhi oleh konstaanta nya, jika konstantanya (r) semakin besar maka jumlah kasus positif akan semakin besar juga, tetapi jika konstanta (r) nya mengecil maka kasus positif akan melandai. Menurut analisa kami juga konstanta ini dapat mengecil jika kita senantiasa mematuhi protokol kesehatan yang sudah dianjurkan pemeritah kita, seperti, mencuci tangan , memakai masker, menjaga jarak, menjauhi kerumunan, dan dengan melakukan Vaksinasi akan memperkecil konstanta tadi dan membuat kasus positif menjadi landai.

\section{Daftar Pustaka}

Boyce William, E. C. (2008). Elementary Diferential and Boundary Value Problems. New York: Grafton

Kurniawan, A., Holisin, I., \& Kristanti, F. (2017). Aplikasi Persamaan Diferensial Biasa Model Eksponensial dan Logistik pada Pertumbuhan Penduduk Kota Surabaya. MUST: Journal of Mathematics Education, Science and Technology, 2(1), 129-141.

Nuraeni, Z. (2017). Aplikasi Persamaan Diferensial dalam Estimasi Jumlah Populasi. Jurnal Ilmiah Pendidikan Matematika, 5(1), 9-16. 